\title{
Perceived Poverty and Alleviation Efforts of Kogi State Community and Social Development Agencies in Kogi State: An Empirical Investigation
}

\author{
Abubakar Ibrahim Jibo Ph.D, FCNA, CIPSM* \\ Bursary Department, Kogi State University, Anyigba
}

\begin{abstract}
This study investigated the perceived poverty and alleviation efforts of Kogi State Community and Social Development Agencies in Kogi State. The study adopted survey research design. The survey was conducted on selected rural areas of Kogi State. Snowball sampling method (which involves referral of respondents) was used, and the total of 300 respondents was surveyed. The sampling procedure adopted for the study was simple random sampling. Data were analysed in tables using percentage and Ordered Probit Regression. Findings show that poor rural roads and inaccessible water supply significantly and negatively affect the socio-economic development of Kogi State; and that massive rural-urban drift and conducive educational environment created by private schools have positively contributed to the socio-economic development of Kogi State. Findings further show that coordinated management, commitment and discipline on the part of the members of the agencies have significant negative effect on the efforts towards poverty reduction in Kogi State; and that over-politization, regular payment and monitoring logistics are seen to have significant positive effect on the efforts towards poverty reduction in Kogi State. The study recommended that the government and economic stakeholders should pay more attention to poor rural roads and inaccessible water supply as they significantly affect the socioeconomic development of Kogi State. Also, the government should intervene in the procurement of alternative source of power supply and encourage increased number of private schools to complement effort on the socioeconomic development process of Kogi State.
\end{abstract}

Keywords: Poverty Alleviation, Socio-Economic Development, Inaccessible Water Supply, Monitoring Logistics, Massive Rural-Urban Drift

DOI: $10.7176 / \mathrm{JPID} / 52-05$

Publication date: January $31^{\text {st }} 2020$

\section{Introduction}

The Nigerian State had been hit by the twin problems of poverty and under-development. According to Omoniyi (2018), about 100 million of the citizens of Nigeria live below the poverty line of \$1 per day. Kogi State is said in common parlance to be one of the poorest states of the Nigerian federation. The Kogi State MDG report of 1990-2006 asserted that the status of poverty incidence in the state is not only very high but consistently above the national average within the period of that study. For example, the incidence of poverty in the state in 1996 was about $87.3 \%$ (relative poverty). By 2005, the percentage of population of the state living in relative poverty (consuming 2,900 calories or lower) was about $89.62 \%$. The study puts the percentage of the population whose expenditures are less than one dollar a day and considered to be poor at $87.46 \%$ (CWIQ, 2006), with $82.71 \%$ of them to be food poor.

The worrying aspect of the Kogi State poverty phenomenon is that rather than being abated, poverty seems to be on the rise. This may be attributed to a number of factors, some of which are mismanagement of human and material resources, indiscipline, the lack of political will by the government of the country, beginning from the post-independence and present day Nigeria. Niazi and Khan (2012) and Haveman (2013) added that labour market issues (unemployment), low level of education, age and family structure and bad culture are associated with poverty. Finding from the study of Akhtar, Liu and Ali (2017) prove that education enrolment domestic credit and inflation have significant impact on poverty in long run. Likewise, Janjua and Kamal (2011) found that education and income have a pivot role in poverty alleviation. Also, Gupta and Mitra (2004) uphold that health influence poverty. These factors are possibly the reason why poverty continues to skyrocket in Kogi State. The approach towards combatting poverty in Kogi State must consider the effects of these factors.

It is unfortunate that policy makers or politicians despised tackling poverty from the root, but have been preoccupied with the conversion of leadership positions and public offices into avenues of squander mania, embezzlement, corruption and money laundering abroad; neglecting the living standard of people and development. Salifu (2010) expressed that these problems (particularly corruption, lack of accountability and lack of consultation with community leaders) limit efforts towards rural development and poverty reduction. Thus, the development effort through variety of socio-economic projects aimed at reducing poverty still remains a mirage. The socio-economic characteristic of the state reveals that the state economy is largely rural with the bulk $(90 \%)$ of the population living in rural areas. Over $80 \%$ of the total populace are engaged in traditional 
agricultural practices. Informal sector activities undertaken on a Small and Medium scale include trade and commerce in agricultural and manufactured goods, tailoring services, auto repairs, metal works, carpentry, food processing, and masonry, (KO-SEEDS 2004). The structure of the state economy has not changed significantly over the years in spite of the relative economic development that has taken place in the country since independence.

Kogi State is characterized by the inadequate existence of the various socio-economic infrastructures essential for economic development. Like in most poor economies, Kogi State is devoid of adequate access and availability of good health care system; conducive educational environment, structures and facilities; good/safe potable drinking water; all-season motorable roads; electrical source of energy; modern market structures and facilities; environmental/ecological and sanitation control. Agencies targeted at poverty reduction in the state among others include Kogi state DFRRI now Directorate for Rural Development (DRD) and Kogi state NAPEP. The agencies are obliged to address issues of poor rural roads, impure and often inaccessible water supply, almost non-existent electricity supply, inadequate housing facilities, and the massive rural-urban drift of able bodied youths that usually results in many societal problems. It is appalling that these remain gaps when poverty alleviation is assessed based on the efforts of the agencies. The gaps occur as a result of over-centralization, unsustainable design, uncoordinated management, over-politization, irregular payment, and lack of monitoring logistics and corruption (Abdullahi, 2008).

\subsection{Research Questions}

In spite of all these, the rural communities of Kogi State still remain poor. It is thus important to answer the following research questions that:

i. What are the factors affecting the efforts of Kogi State Community and Social Development Agencies towards poverty reduction in Kogi State?

ii. What are the effects of poor rural roads, impure and often inaccessible water supply, almost nonexistent electricity supply, inadequate housing facilities, and the massive rural-urban drift of able bodied youths on the socio-economic development of Kogi State?

\subsection{Objectives of the Study}

The main objective of this study is to investigate the perceived poverty and alleviation efforts of Kogi State Community and Social Development Agencies in Kogi State. The specific objectives of the study are to:

i. Determine the significant factors affecting the efforts of Kogi State Community and Social Development Agencies towards poverty reduction in Kogi State.

ii. Assess the significant effects of poor rural roads, impure and often inaccessible water supply, almost non-existent electricity supply, inadequate housing facilities, and the massive rural-urban drift of able bodied youths on the socio-economic development of Kogi State.

\section{Literature Review}

One of the major issues in development is how to tackle rural poverty. The constraints to developing rural areas as well as the problems of this critical sector have come to loom very large. Rural areas present problems that are paradoxical of its natural resource endowment. Rural communities are marginalized in terms of most basic elements of development. The inhabitants tend to live at the margin of existence and opportunities as most rural communities lack portable water, electricity, health care, educational and recreational facilities and motorable roads.

The word poverty has been variously defined and described by many authorities in different ways. For instance Ezekiel (2008) sees poverty as the denial of human rights and human dignity; it means insecurity, powerlessness, exposure to violence, discrimination and exclusion from the stream of the society. According to Nguyet (2003:36), poverty refers to the state of a part of the population that is not provided with the basic human needs that is in accordance with the socio-economic development level and local habits of the nation. UNDP (1999:12) views poverty as the state of being deprived of those opportunities and choices that are essential to human development for a long, healthy, creative life; for a reasonable standard of living; for freedom, dignity, self-respect and respect from others.

According to World Bank (2002:46), "poverty" is pronounced deprivation in well-being, where well-being can be measured by an individual's possession of income, health, nutrition, education, assets, housing, and certain rights in a society, such as freedom of speech. Also poverty is lack of opportunities, powerlessness, and vulnerability defined as the probability or risk today of being in poverty or falling deeper into poverty in the future and is a key dimension of well-being since it affects individual's behavior (in terms of investment, production patterns, coping strategies and the perception of their own situation. It is a situation where an individual is not able to cater adequately for his/her basic need for food, clothing and shelter, social and economic obligations, lacks gainful employment and infrastructure such as education, health, portable water and 
sanitation and consequently has limited chances of advancing his welfare to the limit of his capabilities.

Statistical agencies and researchers through out the world, responding to different concerns are utilizing two very broad concepts of poverty today. One is the concept of absolute poverty, understood as the minimum set of resources a person needs to survive. The other is the concept of relative poverty, a measurement resources and living conditions of parts of the population in relation to the other. Absolute poverty is a matter of acute deprivation, hunger, premature death and sufferings while relative poverty is clearly a matter of social equity. Procacci (2007:5) views poverty as a problem of marginalization. According to him, as far as poverty is concerned, the fundamental right to a minimum of resources for not starving is not enough for organizing a social response to its increase. He buttresses further by saying that social exclusion confirms a dual society and appears more as a symptom of a social fracture than as a solution against it.

A major problem with the literature on poverty alleviation and development as far as this study is concerned is that most works tend to focus more on poverty and development in general rather than being specific on alleviation efforts of individual states in Nigeria. Oguche (2004) noted that majority of Nigerian and people of Kogi State in particular are still living in poverty with a very low standard of living. In terms of countries, Nigeria cannot be considered to be poor because it has enough, and has the capacity to eliminate poverty in the country. This explicitly explains why the foreign creditors have not granted debt cancellation to Nigeria. Nigeria is not poor in terms of resources but poor in terms of management. Oyedeji (2016) observed that "poverty exists when the quantity of resources available to a person is less than some particular quantity of resources needed by that person."

Despite several coordinated programmes for alleviating poverty in Nigeria such as Green Revolution, Operation Feed the Nation, National Agricultural and Rural Development Authority, Directorate of Food, Roads and Rural Infrastructure, National Poverty Eradication Programmes etc. the population of the poor has continue to rise. The socio-economic development of Kogi State is been observed appalling due to rise in the population of the poor. No society can develop if there is a high level of poverty, unemployment, illiteracy, malnutrition, child mortality, political instability and inequity in income distribution. The outcomes of the various development efforts, however, indicate that, there have been serious problems with the implementation of development plans considering the social and political aspects of poverty, which had impacted on the people very severely.

With regards to the health sector, for instance substantial resources have gone into the improvement of health services. Indeed, a recent study of the health sector in Nigeria indicates that, the country is lagging behind in both the absolute level of mortality and its rate of exchange. There appear to be many factors associating with this backdrop. Of the various factors militating against improvement in health status, four appear to be very critical. First is the lack of proper motivation for the available personnel. The second is the critical shortage of essential health facilities as well as media supplies and equipment. The third is the institutional constraints arising from the separation of responsibilities for the management of health facilities by levels of government. The fourth is the problem of inadequate funding by the government. Government expenditure on health has been fluctuating widely and has declined considerably in recent times.

The education system has witnessed considerable expansion over the past twenty years until recently. Public sectors funding of education has been grossly inadequate in recent times. Education expenditure represented an average of 5.1 percent of total federal government expenditures between 1981 and 1991 with a range from 2 percent of total budgetary allocation in 1987 to 8.3 percent in 1989 . In real terms, federal expenditure on education in 1989 was only 68 percent and in 1981. As a percentage of GDP the expenditure averaged about 1.1 percent during the period (see World Bank, 1993). Oyedeji (2016) stated that:

The allocation to education was N249.086billion in 2010, N306.3billion in 2011, N400.15billion in 2012, N426.53billion in 2013, N493billion in 2014 and N492.34billion in 2015. Recent allocations by the federal government to education have shown marginal yearly decreases; N367.73 billion (6.01 percent) in 2016 and N448.01billion (6 percent) of the N7.30 trillion budget.

Ameh and Aluko (2019) showed that the 'education sector got N620.5bn (about 7.05 per cent), marginal raise over the total of $\mathrm{N} 605.8 \mathrm{bn}$ budgeted for the sector in 2018'. The problem of funding seems to be more acute at the tertiary level. This is evidence by the frequent trade disputes between the university lecturers and the federal government concerning the issues of funding and emoluments. Inability to find a lasting solution has exacerbated the deterioration in the quality of the teaching and level of staffing.

The socio-economic characteristic of Kogi State reveals that the state economy is largely rural with the bulk $(90 \%)$ of the population living in rural areas. Over $80 \%$ of the total populace are engaged in traditional agricultural practices. Informal sector activities undertaken on a small-medium scale include trade and commerce in agricultural and manufactured goods, tailoring services, auto repairs, metal works, carpentry, food processing, and masonry, (KO-SEEDS 2004). The structure of the state economy has not changed significantly over the years in spite of the relative economic development that has taken place in the country since 
independence. As in many rural economies, the state is characterized by the inadequate existence of the various socio-economic infrastructures essential for economic development. Like in most poor economies, Kogi State is devoid of adequate access and availability of good health care system; conducive educational environment, structures and facilities; good/safe, potable drinking water; all-season motorable roads; electrical source of energy; modern market structures and facilities; environmental/ecological and sanitation control, etc.

\section{Research Methodology}

The study used survey research design. The survey was conducted on selected rural areas of Kogi State. Kogi State which came into being in 1991 is one of the thirty-six (36) states of Nigeria and was created out of the defunct Kabba Province of the defunct Northern Region. There are 21 Local Government Councils which are further subdivided into three (3) senatorial zones (Kogi Central, Kogi East and Kogi West). Thus, the three senatorial districts and the local government areas that constitutes them are as follows

i. Kogi East Senatorial Zone comprises of: Ankpa LGA, Bassa LGA, Dekina LGA, Idah LGA, Ibaji LGA, IgalaMela-Odolu LGA, Ofu LGA, Omala LGA and Olamaboro LGA.

ii. Kogi Central Senatorial Zone comprises of: Okene LGA, Adavi LGA, Okehi LGA, Ajaokuta LGA and Ogori-Magongo LGA.

iii. Kogi West Senatorial Zone comprises of: Ijumu LGA, Kabba-Bunu LGA, Kogi LGA, Lokoja LGA, Mopa-Amuro LGA, Yagba-West LGA and Yagba-East LGA.

The selected rural areas of these zones were surveyed. The study used well-structured questionnaire for the survey. Snowball method (which involves referral of respondents) was used, and the total of 300 respondents was surveyed. The sampling procedure adopted for the study was stratified simple random sampling. The three senatorial districts were divided into local government while independent sample were selected through simple random procedure. 100 elements or respondents were randomly selected from each of the three local governments. Respondents who were readily available in the time of the survey were served questionnaires. Those who are not available or have health challenges were excluded. Asika (1991:55) noted that the usefulness of the criteria lies in its ability to assist the researcher, develop a mental image of the structure for gathering data and the analysis that follows. Data were analysed in tables using percentage and Ordered Probit Regression.

4. Analysis and Results

Table 1: Demographic Characteristics of Respondents

\begin{tabular}{|c|c|c|}
\hline Demography & Frequency & Percentage \\
\hline \multicolumn{3}{|l|}{ Gender } \\
\hline Male & 211 & 70.33 \\
\hline Female & 89 & 29.67 \\
\hline Total & 300 & 100 \\
\hline \multicolumn{3}{|c|}{ Categorization of Persons by Status } \\
\hline Community Leaders & 75 & 25.0 \\
\hline Rural Women & 31 & 10.33 \\
\hline Youths & 90 & 30.0 \\
\hline Local Government Officials & 93 & 31.0 \\
\hline Vulnerable Groups & 11 & 3.67 \\
\hline Total & 300 & $100 \%$ \\
\hline \multicolumn{3}{|l|}{ Age } \\
\hline $18-27$ & 51 & 17.0 \\
\hline 28-37 & 121 & 40.3 \\
\hline 38-47 & 101 & 33.7 \\
\hline 48 and above & 27 & 9.0 \\
\hline Total & 300 & 100 \\
\hline \multicolumn{3}{|l|}{ Marital status } \\
\hline Married & 194 & 64.7 \\
\hline Single & 92 & 30.7 \\
\hline Divorced & 14 & 4.6 \\
\hline Total & 300 & 100 \\
\hline \multicolumn{3}{|l|}{ Educational Qualification } \\
\hline Higher Degrees & 30 & 10 \\
\hline Degree/HND & 63 & 21 \\
\hline OND/NCE & 96 & 32 \\
\hline SEC/PRI & 60 & 20 \\
\hline No Formal Education & 51 & 17 \\
\hline
\end{tabular}




\begin{tabular}{lcc}
\hline Total & & $\mathbf{1 0 0}$ \\
Occupation & $\mathbf{3 0 0}$ & 28.7 \\
Civil servant & & 41.3 \\
Farmer & 86 & 9.0 \\
Trader & 124 & 16.0 \\
Self-employed & 27 & 5.0 \\
Unemployed & 48 & $\mathbf{1 0 0}$ \\
Total & 15 & $\mathbf{3 0 0}$ \\
\hline Source:
\end{tabular}

Source: Field Survey, 2013

Table 1 above shows the gender distribution of the 300 respondents which formed the sampled population for the study. Out of the 300 participants in this study, 211 respondents representing $70.33 \%$ were males and 89 of the respondents, representing $29.67 \%$ were females. All the participants in the study were drawn randomly from the three local government's areas with one each from the three Senatorial District of the State. From the table above, the low percentage of female participation $(29.67 \%)$ indicates gender bias occasioned by possible cultural affiliations noticeable in our state life; therefore the researcher considers the distribution satisfactory for analysis.

Table 1 above indicates the categorization of persons by status. Responses from the respondents show that 75 of them representing $25 \%$ are Community Leaders, and 31 which represent $10.33 \%$ are rural women. Also 90 respondents representing 30\% are youths. 93 respondents representing 31\% are Local Government Officials, while 11 respondents representing $3.67 \%$ are vulnerable groups.

The result of the study in table 1: shows that 51 respondents representing $17 \%$ had their age range from 18 years to 27 years while majority $(40.2 \%)$ of the respondents had their ages between $28-37$ years. This age bracket falls within the productive labour force and vibrant active population of the State who are likely beneficiaries of governments' poverty alleviation programme. 121 respondents representing $33.7 \%$ fall between the age brackets of 38-47years of age while 27 respondents representing $9 \%$ fall between the age brackets of 48 years and above.

The result of the study in table 1 shows that 194 respondents representing $64.7 \%$. Majority were married, $30.7 \%$ were single and $4.6 \%$ were divorced. This shows that there are predominantly more married people in the communities than those who are not married or divorced.

The result of the study in table 1 shows that 30 respondents representing $10 \%$ had received Higher Degrees while $32 \%$ of the respondents had received OND/NCE education. $21 \%$ had degree/HND and 20\% had received only primary/secondary education. $17 \%$ had received no form of formal education.

The result of the study in table 1 shows that 86 respondents representing $28.7 \%$ were civil servants while $9 \%$ are traders. An overwhelming $41.3 \%$ of the respondents were farmers while $16.0 \%$ were self-employed and $5.0 \%$ are unemployed.

Table 2: Probit Regression result of factors affecting the efforts of Kogi State Community and Social Development Agencies towards poverty reduction in Kogi State

\begin{tabular}{|c|c|c|c|c|}
\hline Code & Variables & Coefficients & Standard Error & P-Value \\
\hline $\mathbf{X}_{1}$ & Over-centralization of task & -.453 & .3114 & .275 \\
\hline $\mathbf{X}_{2}$ & Sustainable design & .196 & .4493 & .254 \\
\hline $\mathbf{X}_{3}$ & Coordinated management & -.328 & .4982 & $.001 * *$ \\
\hline $\mathbf{X}_{4}$ & Over-politization & .389 & .4746 & $.001 * *$ \\
\hline $\mathbf{X}_{5}$ & Regular payment & .567 & .7983 & $.005 * *$ \\
\hline $\mathbf{X}_{6}$ & Monitoring logistics & .587 & .7846 & $.035^{*}$ \\
\hline $\mathbf{X}_{7}$ & Corruption & .200 & .5052 & .125 \\
\hline $\mathbf{X}_{8}$ & Commitment & -.564 & .7768 & $.050 *$ \\
\hline $\mathbf{X}_{9}$ & Discipline & -.695 & .8576 & $.054 *$ \\
\hline \multicolumn{2}{|c|}{$\mathbf{R}^{2}$ (Probit) } & \multicolumn{3}{|c|}{.5446} \\
\hline \multicolumn{2}{|c|}{ PR chi $^{2}$} & \multicolumn{3}{|c|}{87.345} \\
\hline \multicolumn{2}{|c|}{ Prob $>$ chi $^{2}$} & \multicolumn{3}{|c|}{.000} \\
\hline \multicolumn{2}{|c|}{ Parallelism test } & \multicolumn{3}{|c|}{21.451} \\
\hline \multicolumn{2}{|c|}{ Number of Obs } & \multicolumn{3}{|c|}{330} \\
\hline
\end{tabular}

Source: Field Survey, 2013

The p-values* and ** denote $5 \%$ and $1 \%$ significance respectively

Table 2 shows the result of the Ordered Probit Regression on the factors affecting the efforts of Kogi State Community and Social Development Agencies towards poverty reduction in Kogi State. The PR chi ${ }^{2}$ is 87.345 . The Pearson goodness-of-fit chi-square statistic tests the null hypothesis that the model adequately fits the data. The Parallelism test (21.451) shows that the assumption of equal slopes across factor levels is reasonable. The 
significance value of the test is small (less than 0.05); therefore, the model does adequately fit the data. It is thus appropriate to say that the data do not violate the model assumptions. The goodness-of-fit statistics are based on the cell counts and residuals table. Prob $>\mathrm{chi}^{2}=0.001$ implies that $100 \%$ of the changes in the perceived poverty reduction were explained by the variables in the model. The natural response rate is the probability that poverty reduction will be affected given the factors.

The $\mathrm{R}^{2}$ (Probit) of 0.5446 shows that about $54.46 \%$ of poverty reduction is explained by the significant factors. Table 2 shows that coordinated management $(\beta=-0.328$; $p$-value $=0.001)$; commitment $(\beta=-0.564 ; p$ value $=0.05)$; and indiscipline $(\beta=-0.695 ; p$-value $=0.05)$ negatively entered the model. These imply that $32.8 \%$ increase in coordinated management on the part of agencies causes about $32.8 \%$ decrease in the poverty reduction; $56.4 \%$ increased commitment will inversely cause about $56.4 \%$ decrease in poverty reduction in Kogi State; and $69.5 \%$ increasing level of discipline will cause poverty reduction in Kogi State to decrease.

From the table 2 , it is depicted that over-politization $(\beta=0.389$; $p$-value $=0.01)$; regular payment $(\beta=0.567$; $\mathrm{p}$-value $=0.01)$; and monitoring of logistics $(\beta=0.587 ; \mathrm{p}$-value $=0.04)$ positively entered the model. These imply also that $38.9 \%$ increase in over-politization will lead to proportional increase in poverty reduction; $56.7 \%$ change in regular payment will cause almost the same change in poverty reduction; and $58.7 \%$ change in the monitoring of logistics will lead to proportional change in the poverty reduction in Kogi State. Factors such as over-centralization of task $(\beta=-0.453$; $p$-value $=0.275)$, sustainable design $(\beta=0.196$; $p$-value $=0.254)$ and corruption $(\beta=0.200 ; p$-value $=0.125)$ appear to be insignificant.

Table 3: Probit Regression result on effects of factors on the socio-economic development of Kogi State

\begin{tabular}{|c|c|c|c|c|}
\hline Code & Variables & Coefficients & Standard Error & P-Value \\
\hline $\mathbf{X}_{1}$ & Poor rural roads & -.285 & .4750 & $.001 * *$ \\
\hline $\mathbf{X}_{2}$ & Impure and often inaccessible water supply & -.456 & .5269 & $.001 * *$ \\
\hline $\mathbf{X}_{3}$ & Irregular electricity supply & .657 & .3867 & $.035^{*}$ \\
\hline $\mathbf{X}_{4}$ & Inadequate housing facilities & -.376 & .4657 & .670 \\
\hline $\mathbf{X}_{5}$ & Massive rural-urban drift & .245 & .3980 & $.004 * *$ \\
\hline $\mathbf{X}_{6}$ & Inadequate access to good health care system & .782 & .4770 & $.018 * *$ \\
\hline $\mathbf{X}_{7}$ & Unconducive educational environment & .196 & .2770 & $.001 * *$ \\
\hline $\mathbf{X}_{8}$ & Modern market structures and facilities & .362 & .3224 & .440 \\
\hline $\mathbf{X}_{9}$ & Environmental and sanitation control & .468 & .3265 & .250 \\
\hline \multicolumn{2}{|c|}{$\mathbf{R}^{2}$ (Probit) } & \multicolumn{3}{|c|}{.6845} \\
\hline \multicolumn{2}{|c|}{ PR chi $^{2}$} & \multicolumn{3}{|c|}{101.745} \\
\hline \multicolumn{2}{|c|}{ Prob $>$ chi $^{2}$} & \multicolumn{3}{|c|}{.001} \\
\hline \multicolumn{2}{|c|}{ Parallelism test } & \multicolumn{3}{|c|}{4.157} \\
\hline \multicolumn{2}{|c|}{ Number of Obs } & \multicolumn{3}{|c|}{330} \\
\hline
\end{tabular}

Source: Field Survey, 2013

The p-values* and $* *$ denote $5 \%$ and $1 \%$ significance respectively

Table 3 shows the result of the Ordered Probit Regression on the factors and the perceived socio-economic development of Kogi State. The PR $\mathrm{chi}^{2}$ is 101.745 . The Pearson goodness-of-fit chi-square statistic tests the null hypothesis that the model adequately fits the data. The Parallelism test (4.157) shows that the assumption of equal slopes across factor levels is reasonable. The significance value of the test is small (less than 0.05); therefore, the model does adequately fit the data. It is thus appropriate to say that the data do not violate the model assumptions. The goodness-of-fit statistics are based on the cell counts and residuals table. Prob $>\mathrm{chi}^{2}=$ 0.001 implies that $100 \%$ of the changes in the socio-economic development were explained by the variables in the model. The natural response rate is the probability that the socio-economic development of Kogi State be affected given the internal factors.

The $\mathrm{R}^{2}$ (Probit) of 0.6845 shows that about $68.5 \%$ of the perceived socio-economic development of Kogi State is explained by the significant factors (poor rural roads, impure and often inaccessible water supply, irregular electricity supply, massive rural-urban drift, inadequate access to good health care system and unconducive educational environment). The implication of this is that factors (poor rural roads, impure and often inaccessible water supply, irregular electricity supply, massive rural-urban drift, inadequate access to good health care system and unconducive educational environment) affect the perceived socio-economic development significantly in Kogi State.

It is observed that poor rural roads, impure and often inaccessible water supply and inadequate housing facilities entered the model with a negative sign, which implies that increase in these factors lead to a probability decrease in the socio-economic development of Kogi State. The implication of these results is that good rural road, accessible potable water and adequate housing facilities are strong indicators of the socio-economic development of Kogi State. The disappearance of these variables may often indicate that the socio-economic development of Kogi State still suffers a setback. Factors (such as irregular electricity supply, massive ruralurban drift, inadequate access to good health care system, unconducive educational environment) positively 
affect the socio-economic development of Kogi State. The results proved contrary to the a-priori expectation of the study. This may occur as a result of the fact that Kogi State is now over-shadowed with several alternatives towards making living appreciable. For instance, people now have other way of generating power (solar system installation, generator, plants and so on) for personal or business purpose. Also, there are good number of private health care centres and private schools that ascertain conducive educational environment. These among others have contributed to the socio-economic development of Kogi State with little or no effort on the part of the agencies.

\section{Conclusion and Recommendations}

Poverty alleviation agencies have different orientation and strategic focus. It is however observed that their effort is to proffer solutions to poor rural roads, impure and often inaccessible water supply, irregular electricity supply, inadequate housing facilities, massive rural-urban drift, inadequate access to good health care system, unconducive educational environment, modern market structures and facilities and environmental and sanitation control. It is empirically proven that poor rural roads and inaccessible water supply significantly and negatively affect the socio-economic development of Kogi State. The people of Kogi State have found alternative to irregular power supply. The massive rural-urban drift and increasing number of private schools have positively contributed to the socio-economic development of Kogi State.

The effort of poverty alleviation agencies appeared to be affected by factors such as over-centralization of task, sustainable design, coordinated management, over-politization, regular payment, monitoring logistics, corruption, commitment and discipline. Coordinated management, commitment and discipline on the part of the members of the agencies have been empirically proven to have significant negative effect on the efforts towards poverty reduction in Kogi State. There is a suspected uncoordinated management, lack of commitment and discipline on the part of the members of the agencies. Over-politization, regular payment and monitoring logistics are seen to have significant positive effect on the efforts towards poverty reduction in Kogi State. Thus, it is recommended that:

i. The government and economic stakeholders should pay more attention to poor rural roads and inaccessible water supply as they significantly affect the socio-economic development of Kogi State. Also, the government should intervene in the procurement of alternative source of power supply and encourage increased number of private schools to complement effort on the socio-economic development process of Kogi State.

ii. Kogi State Community and Social Development Agencies should effectively invest time in coordinated management, commitment and discipline on the part of the members of the agencies. Over-politization, regular payment and monitoring of logistics should be maintained as they influence efforts towards poverty reduction in Kogi State.

\section{REFERENCES}

Akhtar, R., Liu, H. and Ali, A. (2017). Influencing Factors of Poverty in Pakistan: Time Series Analysis. International Journal of Economics and Financial Issues. 7(2): 215-222.

Ameh, J. and Aluko, O. (Jan., 2019). 2019 Budget: Education gets N620.5bn, against UNESCO's advice. Retrieved on 21/07/2018 from https://punchng.com/2019-budget-education-gets-n620-5bn-against-unescosadvice/

Ezekiel, O.O (2008), "Women and Poverty Reduction in Nigeria from Rhetoric to Action". Retrieve on 20/08/2018 from: http://www.stclements.edu.

Gupta, I. and Mitra, A. (2004), Economic growth, health and poverty: An exploratory study for India. Development Policy Review, 22(2), 193-206.

Haveman, R. (2013). Causes of Poverty. Teaching Poverty 101. Retrieved on 12/05/2018 fromhttps://www.irp.wisc.edu/newsevents/workshops/teachingpoverty101/participants/Presentations/Have man-CausesofPoverty1.pdf

Janjua, P.Z. and Kamal, U.A. (2011), The role of education and income in poverty alleviation: A cross-country analysis. The Lahore Journal of Economics, 16(1): 143-172

Nguyet, C.N. (2003), “Concepts, Contents and Measurement of Poverty in Vietnam”: National Economic University P.I Journal: 26-36

Niazi, M.I. and Khan, A. (2012), The impact of education on multidimensional poverty across the regions in Punjab. Journal of Elementary Education, 21(1): 77-89.

Omoniyi, B.B. (2018), 'An examination of the causes of poverty on economic growth in Nigeria', Africa's Public Service Delivery and Performance Review. 6(1): 1-10. Retrieved on 23/07/2018 from https:/doi.org/ 10.4102/apsdpr.v6i1.175

Oyedeji, O. (Dec. 16, 2016). 2017 Budget: Again, Nigeria fails to meet UN benchmark on education. Retrieved on 21/07/2018 from https://www.premiumtimesng.com/news/top-news/218097-2017-budget-nigeria-fails- 
meet-un-benchmark-education.html

Salifu, S.N. (2010). Poverty Alleviation Programme in Kogi State. A Thesis: University Of Nigeria, Nsukka UNDP(1999), United Nations Development Programmes Human Development Report

World Bank (1996), "Nigerian Poverty in the Midst of Plenty", Report no. 14733, Washington DC: UNI

World Bank (2000), "Poverty in the Age of Globalization" Washington, D.C. World Bank Publication. 